\title{
An analysis of students' cognitive structures in relation to their environmental sensitivity
}

\author{
Cem Gercek ${ }^{1 \mathrm{a}}$ \\ ${ }^{1}$ Faculty of Education, Department of Mathematics and Science Education, Hacettepe University, \\ Ankara, Turkey
}

\begin{abstract}
One of the basic aims of environment-related subjects included in the biology curriculum is to raise environmental awareness. Yet, the fact that the concepts taught especially in the context of environmental issues are abstract influences meaningful learning. This, in turn, influences behaviours displayed. Exhibiting students' cognitive structures in assuring effective and meaningful concept teaching increases the importance of studies conducted. Unavailability of studies in the literature analysing students' cognitive structures in relation to their sensitivity to the environment demonstrates the importance of this current study. This study aims to analyse students' cognitive structures in relation to their environmental sensitivity. The study employs survey model- one of the qualitative research designs. The study group was composed of 56 high school students in the 2016-2017 academic year. The study group was formed through purposeful sampling. Word Association Test (WAT) was prepared in order to uncover students' cognitive structures in relation to their environmental sensitivity. Having transcribed the data obtained, they were put to content analysis and were transferred to the medium of computer. The results showed that students' cognitive structure concerning their environmental sensitivity was divided into categories.
\end{abstract} Keywords: Student, cognitive structure, environmental sensitivity.

\section{Introduction}

High school biology curriculum is heavily loaded. Therefore, the course students have difficulty with is primarily biology [1]. Students tend to memorise the concepts presented in biology course, which influences meaningful learning and causes misconceptions and alternative concepts. Posner et al (1982) point out that students' misconceptions hinder their understanding and interpreting science subjects.

An examination of biology curriculum demonstrates that the curriculum contains abstract subjects and concepts. Teaching the abstract concepts in biology and shaping them in students' mind can be difficult for teachers [2]. Here, constructivist approach occupies an

\footnotetext{
${ }^{a}$ Corresponding author: cgercek@hacettepe.edu.tr
} 
important place. Constructivist approach is based on two basic principles. The first is that knowledge is not received passively by individuals. The second is that making sense of knowledge assures adjustment and life organisation [2, 3]. It is pointed out in various studies that students have problems in understanding biological concepts, activities and processes $[4,5]$. Pendley, Bretz and Novak attribute those problems to memorising the subjects and to education's failure to set up associations between key concepts and concepts [6]. Considering these problems, it becomes evident that students' knowledge structures should be determined and accurate knowledge structures should be developed. In other words, forming a well organised conceptual framework will assure that students will prefer meaningful learning instead of rote learning [7]. The reason for this is that meaningful learning necessitates students' setting up conceptual associations between students' current knowledge and new knowledge presented to them. If they have incomplete conceptual ties, they have difficulty in learning the new material.

It is clear from studies conducted that cognitive structures are determined through various techniques $[1,5]$. The most established technique in this respect is the technique of word association. The technique has been applied for over 20 years. The purpose of word association technique is to understand the associations students set up between concepts and to correct the misconceptions. Studies conducted in this respect are not restricted to primary and secondary school levels but they were also applied to high school students [8]. Application has two forms: prior to transfer of knowledge to students and after transfer of knowledge. In consequence of the applications, significant data were reached in determining students' cognitive structures $[4,9]$. Therefore, this method is also helpful to constructivist educational system. It provides the opportunity to measure and monitor the knowledge transferred to students. Word association technique, which is also commonly used today, can be applied to all students. Although word association technique is frequently used in traditional system of education, it is used very much in contemporary educational system- that is to say, in constructivist approach.

Studies on conceptual change are based on Piaget's assimilation and accommodation processes in the field of education. Assimilation is the process of including new knowledge in existing cognitive structure. For instance, a child's thinking that he/she should throw the bottle into dustbin after drinking water in it because he/she knows that it is now garbage. The concept of accommodation, on the other hand, is the process of re-shaping the existing cognitive structure according to new incidents $[5,6]$. According to the above given example, with learning that recycling water bottles is important both for nature and for assuring materialistic gain, re-arranging the behaviour by throwing the bottles into recycling bins instead of dustbins exemplifies the concept of accommodation. Although biology education is a discipline interacting with the environment, students cannot associate concepts with the environment and unfortunately they form misconceptions and alternative concepts [10]. This situation, in turn, leads to gaining undesired behaviours. Studies concerning environmental education aim to instil in students desired behaviours in relation to the environment $[11,12]$. Yet, several studies report that individuals do not display environment-related behaviours $[11,12,13]$. Researching the reasons and exhibiting the relevant students' cognitive structures are considered important. Absence of a similar study concerning students' environmental sensitivity and word association test shows the importance of this study.

\subsection{Purpose of the study}

This study seeks answers to the following questions since it aims to analyse high school students' cognitive structures about their environmental sensitivity.

1. How are students' cognitive structures about their sensitivity to the environment? 
2. What are students' views about their sensitivity to the environment?

3. What place does environmental sensitivity occupy in high school biology curriculum?

\section{Method}

The study employs survey model- one of the qualitative research designs. Survey models are the models aiming to describe a current situation [14].

\subsection{Research group}

The study group was composed of 56 (27 male, 29 female) high school students in the 2016-2017 academic year. The study group was formed through purposeful sampling. The selected research group were the high school students at 17 (8 male, 14 female), 18 (13 male, 12 female) and 19 years old ( 6 male, 3 female) and they took part in the research on the basis of volunteering.

\subsection{Data collection tools}

Word association test was used in this research as the tool of data collection. The test contained two parts. In part one, key phrase "Environmental Sensitivity" was written 10 times one under another, and the participants were asked to write a related word opposite each. The participants were allowed 35 seconds for this part. In part two, the students were asked to write a sentence related with "Environmental Sensitivity" in 15 seconds. The overall test lasted 50 seconds.

\subsection{Data analysis}

The data obtained from word association test were put to content analysis and were thus analysed. The concepts were divided into categories by consulting expert opinion according to their relevance. The frequencies of the words in the categories were determined.

\subsection{Validity and reliability}

It is important to perform validity and reliability analyses in studies. For validity, the process of data analysis was described in this study. For reliability, whether or not the concepts represented the categories to which they belonged was evaluated by two experts of the field. The concepts obtained were divided into categories by two experts. The agreement and disagreement between the two experts in terms of coding were determined, and agreement between the coders was found to be $86 \%$.

\section{Findings}

This section presents the findings obtained following the analyses. In relation to the first research problem, students' answers to the word association test about environmental sensitivity are shown in Table 1. According to the Table, 443 concepts concerning students' cognitive structures about environmental sensitivity are divided into 4 categories. Because 10 concepts were meaningless, they were excluded from analysis. 30 students reported fewer than 10 concepts. As is clear from the Table, the biggest number of concepts (15 
concepts) was reported in the category of current environmental problems whereas the smallest number of concepts (6 concepts) was reported in the category of recycling.

Table 1. Categories for students' cognitive structures about environmental sensitivity.

\begin{tabular}{|c|c|c|c|}
\hline Categories & Frequ & $\begin{array}{l}\text { encies of the } \\
\text { concepts }\end{array}$ & $\begin{array}{c}\text { Total } \\
\text { frequencies }\end{array}$ \\
\hline $\begin{array}{l}\text { Current } \\
\text { environmental } \\
\text { problems }\end{array}$ & $\begin{array}{l}\text { Environmental pollution } \\
\text { Cutting down-planting trees } \\
\text { Air pollution } \\
\text { Water pollution } \\
\text { Factories } \\
\text { Carbon release } \\
\text { Cigarettes } \\
\text { Global warming } \\
\text { Noise pollution } \\
\text { Soil pollution } \\
\text { Atmospheric layer } \\
\text { Fossil fuels } \\
\text { Cosmetic products } \\
\text { Holes dug by municipality } \\
\text { Germs }\end{array}$ & $\begin{array}{l}(51) \\
(32) \\
(20) \\
(12) \\
(11) \\
(8) \\
(8) \\
(8) \\
(7) \\
(5) \\
(4) \\
(4) \\
(2) \\
(2) \\
(2)\end{array}$ & 176 \\
\hline $\begin{array}{l}\text { Environmental } \\
\text { effects }\end{array}$ & $\begin{array}{l}\text { Ecological balance } \\
\text { vegetation } \\
\text { Natural life } \\
\text { Deforestation } \\
\text { Died organisms } \\
\text { Producing substances harmful to natur } \\
\text { Natural disasters }\end{array}$ & $\begin{array}{l}(48) \\
(32) \\
(24) \\
(15) \\
(19) \\
(6) \\
(4) \\
\end{array}$ & 148 \\
\hline Social values & $\begin{array}{l}\text { Morals } \\
\text { Consciousness } \\
\text { Street animals } \\
\text { Selfishness } \\
\text { Work on nature } \\
\text { Health }\end{array}$ & $\begin{array}{l}(49) \\
(12) \\
(7) \\
(6) \\
(4) \\
(2)\end{array}$ & 80 \\
\hline Recycling & $\begin{array}{l}\text { Recycle bin } \\
\text { Waste } \\
\text { Rarity of recycling } \\
\text { Organisations } \\
\text { Paper } \\
\text { Saprophyte bacteria } \\
\end{array}$ & $\begin{array}{l}(9) \\
(9) \\
(9) \\
(6) \\
(4) \\
(2)\end{array}$ & 39 \\
\hline
\end{tabular}

In relation to the second research problem, some of the statements made by students about environmental sensitivity are as in the following. 2 of the students did not state their views on environmental sensitivity.

"Environmental sensitivity in general is the respect we should have for

living and non-living things in the area we live."

"Setting up new industrial plants, restricting living creatures' habitat and poisoning them with wastes... this is unfair."

"People throw cigarette ends, food and drinks around thoughtlessly."

"Think of clean environment. For example, you lie on the grass with no litter around and you read your book with bird calls and clean air. How 
nice it would be! If only we were sensitive and conscious and protected our environment and left a good world to the next generation".

"Sensitivity in our environment is related with every living thing's respect for each other. If they do not respect each other and obey environmental rules, it is harmful in every respect."

"I think man's gradually ruining the order of biomes in the world is making our end approach."

"An individual who is respectful to the operation routine of the ecosystem he is in, who performs activities (such as planting trees) without disrupting the routine and by contributing to oxygen recycle and who does not put an end to the life of living things in the environment according to his evaluation is a model individual."

"Environmental sensitivity means balancing our consumption and production without depleting nature."

"One's cultural level is directly proportional to his adopting the world in which he lives and keeping it clean".

In relation to the third problem, on examining the subjects about the environment included in high school biology programme, it is found that a subject called "Current Environmental Problems" is available in Unit 3 of the 9th grade [15]. No subjects were found for the other grade levels. An examination of 9th grade high school biology curriculum makes it clear that the purpose in this unit is to make students aware of the negative effects of human activities on the environment and to make them suggest solutions to relevant problems, to assure that they understand the effects of environmental problems on human health, and to assure that they gain skills, attitudes, values and understanding necessary for biology literacy around the key word "the environment". The unit aims to enable students to have 7 gains in 18 class hours. This unit contains such headings as:

The causes and effects of environmental problems (air, water, soil, radioactive, food and noise pollution, erosion, forest fire, destruction of natural habitats and ecological footprint),

Natural resources (biological diversity, biological diversity in our country and preserving diversity).

And the gains in the unit are as in the following:

- He/she questions the causes and probable effects of current environmental problems.

- He/she questions his/her individual role in the emergence of current environmental problems.

- He/she demonstrates the effects of current environmental problems on human health with examples.

- He/she analyses the social, economic and biological importance of the sustainability of natural resources.

- He/she becomes aware of the importance of biological diversity.

- He/she questions the factors making Turkey rich in biological diversity.

- He/she makes suggestions for solution in preserving biological diversity and shapes his/her suggestions.

\section{Results and discussion}

On examining the categories formed in accordance with the first research problem, it may be said that students are knowledgeable about the subject but that they have incomplete knowledge. An analysis of the concepts in all three categories demonstrates that the categories of social values and of recycling contain the smallest number of concepts. Although concepts such as morals, awareness, separating or evaluating the wastes were 
written, the frequencies of them were high- which was important for sensitivity to the environment (see Figure 1) because gains in this category are reflective of behaviours and attitudes about environmental sensitivity $[11,12,16]$. It is already expected that students forget what they learn in classes over time. Yet, it was found that diminishing in students' knowledge about current environmental problems in the unit was quite high [8].

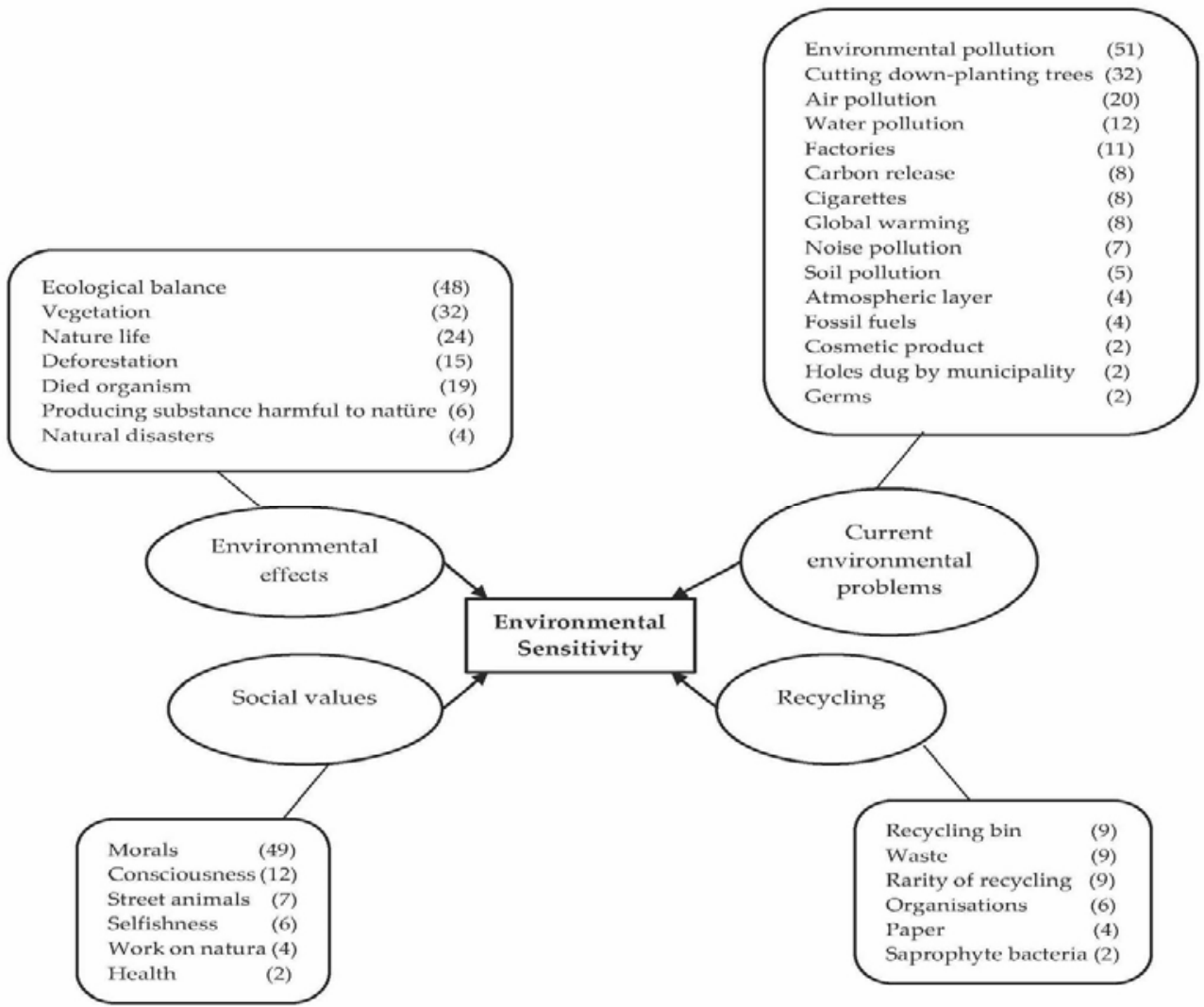

Fig. 1. Model for Students' Cognitive Structure about Environmental Sensitivity.

It was found in relation to the second research problem that students' views of environmental sensitivity were not adequate in providing attitudes and behaviours towards environmental sensitivity. The gains in Unit 3 of 9th grade curriculum [15] are the gains in questioning individuals effects on current environmental problems, demonstrating the impacts on human health with examples, factors assuring biological diversity, and their importance and preserving them. It was remarkable that those gains were not directly about environmental sensitivity. This might have stemmed from the fact that efforts had been made to instil is students the existing gains in a short time.

The formation of environmental sensitivity is the acquisition of determined gains about environmental issues- that is to say, reflection into behaviours. On examining high school biology subjects concerning environmental sensitivity in accordance with the third research problem, we find that the subject of "Current Environmental Problems" is available in Unit three of the 9th grade textbook. No subjects about the environment were available in the units of 10th, 11th and 12th grades [15]. On examining the unit of Current Environmental 
Problems in the 9th grade biology course book, it was found that concepts such as acid rains, erosion, electromagnetic contamination, radioactive contamination, food pollution and ecological foot print were also included as different from the concepts presented by students [15]. This situation may be considered as that students could not learn some concepts and subjects or that they have forgotten them. Failure to have complete learning in environmental sensitivity may cause students' failure to reach the determined gains in relation to the subject.

\section{Implications}

Environmental sensitivity is important for the protection of the environment and of biological diversity and for recycling. When we look around, it is not difficult to see that our sensitivity to the environment is insufficient. It is important that students be taught subjects about the environment and sensitivity to the environment beginning with early ages and to provide them with gains about environmental sensitivity. Misconceptions and alternative concepts they have should be determined prior to and after classes, and they should be eliminated in appropriate methods and techniques. Doing all these and thus gaining sensitivity to the environment at early ages in different grade levels is considered important.

\section{References}

1. M. Bahar, M. H., Hansell, The relationship between some psychological factors and their effect on the performance of grid questions and word association tests, Educational Psychology: An Int. J. of Experimental Educational Psychology, 20, 3, $346-364$ (2000).

2. J. R., Savery, T. M., Duffy, Problem based learning: an instructional model and its construtivist framework. Educational Technology, September-October, 31-38 (1995)

3. J., Piaget, Cognitive development in children: development and learning, J. Research in Science Teaching, 2, 176-186 (1964)

4. M. C. P. J., Knippels, A. J., Waarlo, K.T., Boersma, Design criteria for learning and teaching genetics. J. of Biological Education, 39, 3, 108-112 (2005)

5. H. S., Lee, O. L., Liu, Assessing learning progression of energy concepts across middle school grades: the knowledge integration perspective, Science Education, 94, 4, 665-688 (2010)

6. B. D., Pendley, R. L. Bretz, J. D., Novak, Concept maps as a tool to assess learning in chemistry. J. of Chemical Education, 71, 9-17 (1994)

7. R., Maskill, A. F., Cachapuz, V., Koulaidis, Young pupils' ideas about the microscopic nature of matter in three different European countries, Int. J. of Science Education, 19, 6, 631-645 (1997)

8. G., Polat, Determination of the cognitive structures of year secondary school students through word association test techniques, Necatibey Faculty of Education Electronic J. of Science and Mathematics Education, 7, 1, 97-120 (2013)

9. W., Wagner, J., Valencia, F., Elejabarrieta, Relevance, discourse and the hot stable core of social representation-A structural analysis of word association, British J. of Social Psychology, 35, 331-351 (1996)

10. Z., Kostova, B., Radoynovska, Word association test for studying conceptual structures of teachers and students, Bulgarian J. of Science and Education Policy, 2, 2, 209-231 (2008) 
11. M., Daskolia, A., Dimos, P. G., Kampylis, Secondary teachers' conceptions of creative thinking within the context of environmental education. Int. J. of Environmental and Science Education, 7, 2, 269-290 (2012)

12. G. H., Erol, K., Gezer, Prospective of elementary school teachers' attitudes toward environment and environmental problems. Int. J. of Environmental and Science Education. 1, 1, 65-77 (2006)

13. V.N., Kırtak-Ad, N., Demirci, Prospective teachers' levels of associating environmental problems with science fields and thermodynamics laws, Ahi Evran University Journal of Kirsehir Educatioan Faculty, 13, 3, 19-46 (2012)

14. H., Şimşek A., Yıldırım, Qualitative research methods in the social sciences, Ankara: Seçkin Puplishing (2013)

15. Ministry of National Education of Turkey [MONE] Biyoloji Dersi $(9,10,11$ ve 12. Sinıflar) Öğretim Programı [Secondary Education, Curriculum of Biology Course (Grades 9th-12th)], Retrieved from http://ttkb.meb.gov.tr/program2.aspx., (2013)

16. Z. F., Pluhar, B. F., Piko, S., Kovacs, A., Uzzoli, Air pollution is bad for my health: hungarian children's knowledge of the role of environment in health and disease, Health \& Place, 15, 239-246 (2009) 